\title{
Model Pembelajaran Aktif Course Review Horay (CRH) untuk Meningkatkan Prestasi Belajar Matematika
}

\author{
Sri Hartati a,1,* \\ a SMP Negeri 2 Weru, Karangwuni, Weru, Sukoharjo, Indonesia \\ 1 shartati697@gmail.com* \\ * Corresponding Author
}

Diterima 22 Februari 2021; Disetujui 16 Maret 2021; Diterbitkan 17 Maret 2021

\begin{abstract}
The objective of this study is to improve students' learning outcome on mathematics through the active learning model of Course Review Horay (CRH) in class VII H students of the odd semester of SMP Negeri 2 Weru in the academic year 2019/2020. The subjects of this study are 32 students of class VII H. Data collection techniques are using documentation, observation, and written tests. Data collection tools are the form of observation sheets, test items, and a list of scores. Data analysis use comparative descriptive analysis followed by reflection. Each cycle consists of four steps, namely: (1) Planning, (2) Implementing Actions, (3) observing, and (4) Reflecting. The results show that there is an increase in students 'Mathematics learning achievement, the average score of students' mathematics learning achievement increase, namely before the action was 69.8, in cycle I is 72.9 and in cycle II is 82.9. In addition, the percentage of student learning completeness also increase, namely before the action was $53.1 \%$, cycle I is $65.6 \%$ and cycle II is $93.8 \%$. So it can be concluded that the $\mathrm{CRH}$ active learning model can improve students' learning outcome.
\end{abstract}

KEYWORDS

Student Learning

Achievement

Active Learning

Course Review Horay

This is an openaccess article under the CC-BY-SA license

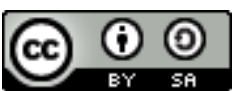

\section{Pendahuluan}

Matematika merupakan salah satu mata pelajaran yang harus diajarkan pada setiap jejang sekolah, khususnya pada sekolah tingkat dasar, menengah, dan atas. Matematika juga menjadi salah satu mata pelajaran yang tidak disukai oleh kebanyakan siswa karena dianggap sulit. Anggapan tersebut membuat siswa enggan untuk belajar dan kurang bersemangat ketika pelajaran matematika. Hal tersebut mengakibatkan hasil belajar matematika siswa yang kurang memuaskan atau masih tergolong rendah (Ayuwanti 2017). Matematika memiliki peran penting dalam kehidupan manusia. Pengetahuan tentang matematika, diperlukan dalam kehidupan sehari-hari maupun dalam mengembangkan kemampuan berfikir kritis, logis, sistematis, objektif dan rasional serta menjadi pondasi bagi berkembangnya teknologi modern (Maryam, Hasbi, and Hamid 2016). Pentingnya matematika dalam pembentukan pola pikir, membutuhkan sebuah proses pembelajaran matematika yang bermakna serta harus mampu menunjukkan manfaat matematika dalam memecahkan berbagai masalah dalam kehidupan. Hal ini meuntut guru untuk lebih kreatif dan inovatif dalam memilih dan menggunakan strategi, pendekatan, metode, maupun teknik pembelajaran yang bisa membuat siswa menjadi lebih aktif, sehingga berdampak pada hasil belajar siswa. (Kusfabianto, Kristin, and Anugraheni 2019). Oleh karena itu, guru diharapkan dapat menciptakan suasana kelas yang menyenangkan sehingga siswa dapat termotivasi dalam belajar Matematika dan dapat menambah keaktifan siswa dalam pembelajaran. Kurangnya suasana kelas yang menyenangkan dan perlu adanya suatu model pembelajaran yang inovatif dan kreatif yang dapat menumbuhkan semangat belajar Matematika dan memperkuat daya ingat siswa terhadap materi yang dipelajari sehingga dapat menunjang terciptanya kegiatan belajar mengajar yang kondusif.

Berdasarkan hasil pengamatan peneliti selaku guru Matematika kelas VII H SMP Negeri 2 Weru, masalah yang dihadapi oleh siswa sejauh ini adalah kurangnya keaktifan dan rendahnya prestasi belajar siswa, salah satunya adalah materi Himpunan. Karena pada bab ini siswa mengenal dan menganalisa berbagai situasi terkait Himpunan. Hal ini dapat dilihat dari kegiatan belajar mengajar di kelas VII H dengan KKM 71, nilai rata-rata hasil ulangan harian Matematika materi Himpunan 
di kelas tersebut yaitu 69,8 dengan persentase ketuntasan sebesar 53,1\%. Rendahnya pemahaman konsep matematika siswa dipengaruhi oleh beberapa hal, salah satu diantaranya adalah model pembelajaran yang digunakan guru. Ketepatan pemilihan model pembelajaran oleh guru akan mempengaruhi proses belajar siswa. Selain itu, pada kegiatan pembelajaran di dalam kelas siswa hanya bersikap pasif, sedangkan yang aktif adalah guru. Sehingga siswa merasa bosan dan kurang termotivasi dalam belajar Matematika (Kasna, Sudhita, and Rati 2015). Oleh karena itu, diperlukan pembelajaran yang dapat mempermudah siswa dalam memahami konsep matematika, serta melibatkan semua siswa agar menjadi lebih aktif dan lebih berkonsentrasi dalam proses pembelajaran (Hadi and Umi Kasum 2015). Guru yang profesional dituntut untuk mampu menguasai delapan keterampilan dasar mengajar, salah satu diantaranya adalah keterampilan mengadakan variasi pengadaan viariasi dalam kegiatan pembelajaran bertujuan untuk membuat suasana belajar menjadi lebih menyenangkan dan tidak membosankan. Karena guru merupakan penentu kualitas pengajaran dalam kegiatan pembelajaran, guru mempunyai tugas untuk mendorong, membimbing, dan memberikan fasilitas belajar bagi siswa untuk mencapai tujuan. (Kasna, Sudhita, and Rati 2015). Salah satu model pembelajaran yang dapat menarik minat siswa dalam belajar salah satunya adalah dengan menempatkan siswa secara berkelompok-kelompok, hal ini dilakukan karena dapat melatih siswa untuk berfikir kritis, kreatif, dan menumbuhkan rasa sosial yang tinggi.(Pratama, Susanto, and Exacta 2020). Berdasarkan kondisi tersebut, maka perlu adanya model pembelajaran yang dapat mendukung terciptanya iklim belajar yang dinamis, tidak membuat siswa jenuh, serta mampu menumbuhkan dan meningkatkan motivasi belajar, memacu kreativitas, serta menumbuhkan interaksi antar siswa dan interaksi antara siswa dengan guru. Jika hal tersebut terwujud, maka memungkinkan siswa untuk mencapai prestasi belajar yang lebih baik. Model pembelajaran yang memungkinkan dapat merealisasikan kondisi tersebut adalah model pembelajaran kooperatif. (Aprilianawati, Nizaruddin, and Prayito 2019). Pembelajaran yang dapat mewujudkan hal tersebut adalah pembelajaran kooperatif. Metode pembelajaran kooperatif selain bermanfaat untuk memperdalam pemahaman materi atau konsep matematika juga dapat dilaksanakan dengan menggunakan pendekatan permainan, sehingga ketika menggunakan metode ini akan tercipta suasana pembelajaran yang lebih kondusif, karena siswa dilibatkan secara aktif dalam suasana belajar yang menyenangkan. (Zakiah, Prasetyo, and Astutiningtyas 2019).

Model pembelajaran kooperatif dapat digunakan untuk meningkatkan aktivitas belajar siswa, sehingga siswa tidak merasa jenuh saat proses pembelajaran. Salah satu model pembelajaran kooperatif yang dapat digunakan adalah model pembelajaran kooperatif tipe Course Review Horay. (Ningrum, Mahadewi, and Japa 2019). Salah satu pendekatan yang dapat digunakan untuk meningkatkan pemahaman dan motivasi belajar adalah pendekatan Course Review Horay (CRH) karena pendekatan pembelajaran tersebut bertujuan untuk meningkatkan pemahaman siswa terkait materi ajar. Hal tersebut dibuktikan dengan adanya latihan soal sebagai bentuk pengujian pemahaman dalam proses pembelajaran yang ditulis pada kartu yang telah disediakan. Sementara ketika pembahasan latihan soal, siswa harus meneriakkan kata 'horee' atau yel-yel lain sebagai bentuk kemenangan karena telah menjawab soal dengan tepat. Dengan demikian, pendekatan CRH dapat digunakan untuk meningkatkan pemahaman matematis siswa yang sekaligus dapat meningkatkan motivasi belajar matematika siswa karena pembelajaran dikemas dengan menyenangkan dan meriah. (Suryani, Maulana, and Julia 2016). Terdapat keterkaitan pemahaman konsep matematis dengan model pembelajaran CRH. Jika dilihat berdasarkan kemandirian belajar siswa, kemandirian belajar siswa saling berkaitan dengan pemahaman konsep matematis dan model pembelajaran CRH. (Muhandaz, Trisnawita, and Risnawati 2018). Model Pembelajaran Course Review Horay adalah sebuah cara belajar-mengajar yang lebih menekankan pada pemahaman materi dengan cara menyelesaikan persoalan. Model Pembelajaran Course Review Horay mampu menciptakan suasana kelas meriah dan menyenangkan karena kelompok yang dapat menjawab pertanyaan dari guru dan bernilai benar maka kelompok tersebut dapat menyuarakan horay atau yelyel kreatif yang dibuat oleh siswa sendiri. Model Pembelajaran Course Review Horay dianggap memiliki berbagai keunggulan yaitu siswa lebih semangat dalam belajar karena pembelajaran dikemas dalam suasana yang menyenangkan serta diselingi dengan hiburan sehingga mampu menciptakan suasana kelas yang asyik dan menyenangkan. Hal ini akan berdampak pada model penyampaian teori yang tidak monoton, serta menarik perhatian siswa untuk fokus pada pelajaran. Sehingga diharapkan tingkat pemahaman siswa menjadi lebih optimal. (Romadhoni and Relmasira 2018). Model Course Review Horay (CRH) memungkinkan guru menciptakan suasana belajar baru 
di kelas. Metode Course Review Horay (CRH) bersifat interaktif sehingga mampu membuat peserta didik lebih santai dalam belajar. (Nurhayati and Marliani 2019). Melalui model pembelajaran ini, siswa bisa belajar dengan menyenangkan tanpa ada rasa tertekan dengan materi yang sedang dipelajari. Model pembelajaran Course Review Horay dapat membuat siswa dengan mudah menyerap konsep-konsep yang dipelajari, sebab siswa terjun langsung dalam memecahkan masalah dalam belajar. Dan harapannya, aktivitas dan hasil belajar matematika dapat ditingkatkan. (Suprihartini 2019). Sama halnya dengan model pembelajaran kooperatif pada umumnya, dimana siswa dikelompokkan dalam kelompok kecil yang heterogen dengan kemampuan akademik yang berbeda maksud dari pembagian ini adalah agar mereka saling belajar, bekerja sama menjadi tutor bagi teman sebayanya dan memastikan bahwa seluruh anggota tim telah menguasai pelajaran tesebut. Pada tahap evaluasi seluruh siswa dalam kelompok diberi tes tentang materi itu, pada saat tes ini mereka tidak diperbolehkan saling membantu. Bedanya dengan model pembelajaran kooperatif tipe lain, pada model pembelajaran kooperatif tipe Course Review Horay (CRH) siswa yang menjawab benar harus menyanyikan Yel - yel kelompok mereka. Kemudian, banyaknya yelyel yang diperoleh anggota yang berasal dari kelompok itu diakumulasikan untuk menjadi nilai kelompok dan kelompok yang memiliki skor tertinggi atau jumlah yelyel yang paling banyak diberi hadiah atau penghargaan oleh guru. Jadi, ciri khas pada model pembelajaran kooperatif tipe Course Review Horay (CRH) ini terletak pada penggunaan yel-yel dalam pembelajaran. Yel-yel yang dinyanyikan dapat menjadi hiburan tersendiri bagi setiap orang yang berada di kelas sehingga suasana belajar menjadi lebih menyenangkan. (Hasibuan 2019). Berdasarkan beberapa hal di atas, maka pada kesempatan kali ini akan dikaji mengenaipenerapan metode Course Review Horay dan pengaruhnya terhadap hasil belajar siswa.

\section{Metode}

Penelitian ini adalah Penelitian Tindakan Kelas (PTK). Penelitian ini dilaksanakan di SMP Negeri 2 Weru. Tahap-tahap pelaksanaan kegiatan dilakukan selama kurang lebih enam bulan yaitu sejak bulan Juli sampai dengan Desember 2019. Peneliti sebagai guru SMP Negeri 2 Weru bertindak sebagai subjek yang melakukan tindakan kelas. Teman sejawat sesama guru mata pelajaran Matematika sebagai observer. Kepala Sekolah bertindak sebagai subjek yang membantu dalam perencanaan dan pengumpulan data. Subjek yang menerima tindakan adalah siswa kelas VII H SMP Negeri 2 Weru semester I tahun pelajaran 2019/2020 sebanyak 32 siswa.

Teknik pengumpulan data yang digunakan adalah: tes, observasi dan dokumentasi. Tes adalah serentetan pertanyaan atau latihan serta alat lain yang digunakan untuk mengukur keterampilan, pengetahuan inteligensi, kemampuan atau bakat yang dimiliki oleh individu dan kelompok. Tes digunakan adalah jenis tes hasil (achievement test) berupa kuis individu. Tes ini digunakan untuk mengukur pencapaian siswa setelah mempelajari materi. Hal ini dapat juga sebagai alat untuk mengetahui tingkat pemahaman siswa setelah mempelajari materi Himpunan dengan menggunakan model pembelajaran aktif CRH. Tes yang digunakan adalah tes uraian yang jawabannya berupa isian berbentuk isian singkat atau uraian. Observasi atau pengamatan dilakukan guna memperoleh data yang akurat, dengan menggunakan lembar observasi. Lembar observasi digunakan untuk memonitor dan mengevaluasi setiap tindakan agar kegiatan observasi tidak terlepas dari konteks permasalahan dan tujuan penelitian.

Observasi yang digunakan adalah observasi sistematis, yaitu observasi yang dilakukan oleh pengamat dengan menggunakan pedoman sebagai instrumen pengamatan dan observasi nonsistematis yang dilakukan dengan tidak menggunakan instrumen pengamatan. Dokumentasi diperoleh dari hasil kuis siswa, lembar observasi, lembar wawancara, catatan lapangan, daftar siswa, dan foto-foto selama proses kegiatan belajar mengajar. Dokumentasi ini dimaksudkan adalah sebagai bukti-bukti konkret dari penelitian tindakan kelas tersebut.

Instrumen yang digunakan dalam penelitian berupa tes, lembar observasi dan lembar dokumentasi, yang menjelaskan dan menyatakan himpunan, himpunan bagian, himpunan semesta, himpunan kosong, komplemen himpunan menggunakan masalah konstektual. Tes berbentuk tes tertulis maupun lisan yang dilakukan dalam post test dan kuis individu. Tes ini digunakan untuk mengetahui sejauh mana peningkatan prestasi belajar dengan penerapan model pembelajaran aktif CRH. Lembar Observasi, digunakan lembar observasi pelaksanaan pembelajaran aktif CRH. Lembar dokumentasi bertujuan untuk mengetahui data siswa selama kegiatan penelitian 
berlangsung. Lembar dokumentasi ini berupa, foto-foto kegiatan pembelajaran, daftar hadir kegiatan pembelajaran, daftar hadir, daftar nilai, kartu pasangan soal/jawaban dan sebagainya.

Indikator keberhasilan kinerja dalam penelitian ini adalah: (1) siswa dianggap mencapai ketuntasan belajar apabila mencapai lebih dari atau sama dengan KKM (KKM 70); (2) pembelajaran dianggap berhasil apabila tingkat ketuntasan kelas mencapai lebih dari atau sama dengan 90\%; dan (3) pembelajaran dianggap berhasil apabila siswa secara klasikal rata-rata mencapai lebih dari atau sama dengan 80 .

\section{Hasil dan Pembahasan}

Deskripsi data hasil penelitian yang telah dilakukan di kelas VII H SMP Negeri 2 Weru adalah sebagai berikut. Berdasarkan observasi awal di kelas VII H mata pelajaran Matematika dengan materi Himpunan diperoleh data, dari 32 siswa yang mencapai nilai kriteria ketuntasan minimal (KKM) sebanyak 17 siswa $(53,1 \%)$, dengan nilai rata-rata kelas sebesar 69,8. Penelitian ini dilakukan dengan indikator kinerja nilai rata-rata tes siswa sekurang-kurangnya 80,0 dan banyak siswa dengan nilai di atas kriteria ketuntasan minimal (KKM) yaitu $\geq 71,0$ mencapai $\geq 85 \%$.

Berdasarkan pengalaman peneliti sebagai guru Matematika kelas VII H, guru masih mendominasi kegiatan pembelajaran dan siswa cenderung tidak aktif. Salah satu solusi yang dikembangkan adalah penggunaan model pembelajaran yang baru yaitu dengan model pembelajaran aktif CRH. Dengan penggunaan model pembelajaran aktif CRH akan menciptakan suasana belajar yang berbeda, bervariasi dan menyenangkan sehingga dapat menarik perhatian siswa, meningkatkan keaktifan siswa yang muara akhirnya meningkatkan prestasi belajar siswa.

Tindakan kelas siklus I dilaksanakan pada hari Selasa, 24 September 2019 di SMP Negeri 2 Weru kelas VII H. Setelah langkah apersepsi dilanjutkan dengan penyampaian materi Himpunan pada KD 3.4 Menjelaskan dan menyatakan himpunan, himpunan bagian, himpunan semesta, himpunan kosong, komplemen himpunan menggunakan masalah kontekstual pada indikator mendeskripsikan pengertian Himpunan, mengidentifikasi Himpunan, dan menyelesaikan masalah yang berkaitan dengan Himpunan dengan model pembelajaran aktif CRH.

Berdasarkan hasil evaluasi pada siklus I menunjukkan adanya peningkatan prestasi belajar siswa. Prestasi belajar siswa sebanyak 21 siswa mencapai nilai kriteria ketuntasan minimal (KKM) atau $65,625 \%$, rata-rata kelas naik menjadi 72,9 . Berdasarkan pengamatan tersebut dapat diketahui bahwa proses pembelajaran pada siklus pertama belum berhasil maksimal dan belum mencapai indikator kinerja yang diharapkan. Peningkatan hasil, jika dibandingkan hasil prasiklus yang mencapai KKM sebanyak 17 siswa atau $53,1 \%$ setelas diberi tindakan penerapan siklus I, siswa yang mencapai KKM sebanyak 21 siswa atau $65,6 \%$.

Tabel 1. Perkembangan Siswa yang Mencapai KKM Sebelum Tindakan/ Prasiklus ke Siklus I

\begin{tabular}{ccc}
\hline Prestasi Siswa & Prasiklus & Siklus I \\
\hline Rata-rata & 69,8 & 72,9 \\
Siswa mencapai KKM & 17 & 21 \\
\hline
\end{tabular}

Dari tabel di atas dapat disimpulkan bahwa prestasi belajar Matematika materi Himpunan pembelajaran aktif CRH, pada pelaksanaan tindakan siklus I mengalami peningkatan. Sebelum dilakukan tindakan atau prasiklus, rata-rata prestasi belajar siswa sebesar 69,8 dan siswa yang mencapai KKM sebanyak 17 siswa, setelah tindakan siklus I, rata-rata prestasi belajar siswa menjadi 72,9 dan siswa yang mencapai KKM sebanyak 21 siswa sehingga meningkat 4 siswa.

Setelah dievaluasi bersama dari pelaksanaan tindakan pada siklus I pembelajaran aktif CRH, belum digunakan secara maksimal, sehingga di siklus II kita akan memaksimalkan pembelajaran aktif $\mathrm{CRH}$, dengan perencanaan perbaikan untuk mengatasi kekurangan dan kesalahan yang dilakukan pada siklus I. Tindakan kelas siklus II dilaksanakan pada hari Selasa, 22 Oktober 2019 dengan materi Himpunan pada KD 3.4 memahami pengetahuan tentang Himpunan (Menjelaskan dan menyatakan himpunan, himpunan bagian, himpunan semesta, himpunan kosong, komplemen himpunan menggunakan masalah kontekstual) pada indikator mendeskripsikan pengertian 
Himpunan, mengidentifikasi Himpunan, dan menyelesaikan masalah yang berkaitan dengan Himpunan. Berdasarkan pembelajaran secara keseluruhan pada tindakan kelas siklus II menunjukan adanya peningkatan yang signifikan. Rata-rata nilai prestasi belajar siswa kelas VII H naik menjadi 82,9 dan sebanyak 30 siswa $(93,8 \%)$ mencapai nilai kriteria ketuntasan minimal (KKM).

Tabel 2. Perkembangan Prestasi Belajar Siswa dari Siklus I ke Siklus II

\begin{tabular}{ccc}
\hline Prestasi Siswa & Siklus I & Siklus II \\
\hline Rata-rata & 72,9 & 82,9 \\
Siswa mencapai KKM & 21 & 30 \\
\hline
\end{tabular}

Dari tabel di atas dapat disimpulkan bahwa prestasi belajar Matematika materi Himpunan dengan menerapkan model pembelajaran aktif $\mathrm{CRH}$, pada pelaksanaan tindakan siklus II mengalami peningkatan. Pada tindakan siklus I, rata-rata prestasi belajar siswa sebesar 72,9 dan siswa yang mencapai KKM sebanyak 21 siswa, setelah tindakan siklus II, rata-rata prestasi belajar siswa menjadi 82,9 dan siswa yang mencapai KKM sebanyak 30 siswa sehingga meningkat 10 siswa. Berdasarkan hasil tersebut dapat diketahui bahwa proses pembelajaran sampai dengan pada siklus II berjalan dengan baik dan telah memenuhi indikator kinerja yang diharapkan.

Pada siklus I dan II dengan penerapan tindakan menggunakan model pembelajaran aktif CRH, siswa lebih antusias dengan perasaan senang dalam mengikuti kegiatan pembelajaran. Nilai rata-rata siswa sejak sebelum diadakan penelitian hingga setelah diadakan penenelitian sampai dengan siklus II, dapat dilihat pada tabel berikut:

Tabel 3. Perkembangan Prestasi Belajar Siswa Sebelum Tindakan/Prasiklus,Siklus I dan Siklus II

\begin{tabular}{cccc}
\hline Prestasi Siswa & Prasiklus & Siklus I & Siklus II \\
\hline Rata-rata & 69,8 & 72,9 & 82,9 \\
Siswa mencapai KKM & 17 & 21 & 30 \\
\hline
\end{tabular}

Dari tabel di atas dapat disimpulkan bahwa hasil belajar materi Segitiga dan Segiempat dengan menerapkan model pembelajaran aktif $\mathrm{CRH}$, di setiap pelaksanaan tindakan, baik siklus I dan siklus II mengalami peningkatan, yaitu: siswa yang mencapai KKM sebelum dilakukan tindakan atau prasiklus 17 siswa, setelah tidakan siklus I sebanyak 21 siswa dan setelah tindakan siklus II sebanyak 30 siswa, sehingga peningkatan kumulatif dari sebelum tindakan/prasiklus sampai dengan siklus II sebesar 13 siswa.

Tabel 4. Perkembangan Persentase Siswa Mencapai KKM Sebelum Tindakan/Prasiklus, Siklus I dan Siklus II

\begin{tabular}{cccc}
\hline Prestasi Siswa & Prasiklus & Siklus I & Siklus II \\
\hline Persentase Siswa Mencapai KKM & $53,1 \%$ & $65,6 \%$ & $93,8 \%$ \\
\hline
\end{tabular}

Dari tabel di atas dapat disimpulkan bahwa prestasi belajar Matematika materi Himpunan dengan menerapkan model pembelajaran aktif $\mathrm{CRH}$, di setiap pelaksanaan tindakan mengalami peningkatan, yaitu: persentase siswa yang mencapai KKM sebelum dilakukan tindakan atau prasiklus $53,1 \%$, setelah tidakan siklus I sebanyak $65,6 \%$ dan setelah tindakan siklus II sebanya $93,8 \%$.

Tabel 5. Perkembangan Nilai Rata-rata Kelas Sebelum Tindakan/Prasiklus, Siklus I dan Siklus II

\begin{tabular}{cccc}
\hline Prestasi Siswa & Prasiklus & Siklus I & Siklus II \\
\hline Nilai rata-rata & 69,8 & 72,9 & 82,9 \\
\hline
\end{tabular}

Dari tabel di atas dapat disimpulkan bahwa prestasi belajar materi Himpunan dengan menerapkan model pembelajaran aktif $\mathrm{CRH}$, di setiap pelaksanaan tindakan mengalami peningkatan, yaitu: nilai rata-rata kelas sebelum dilakukan tindakan atau prasiklus adalah 69,8, setelah tidakan siklus I adalah 72,9 dan setelah tindakan siklus II adalah 82,9 sehingga dari kondisi awal sebelum tindakan/prasiklus sampai dengan tidakan pada siklus II terjadi peningkatan. Dari uraian di atas dapat disimpulkan bahwa model pembelajaran aktif CRH dapat meningkatkan prestasi 
belajar materi Himpunan siswa kelas VII H SMP Negeri 2 Weru semester I tahun pelajaran 2019/ 2020. Pada penelitian kondisi awal, siklus 1, dan siklus 2 diperoleh data yang dapat ditabulasikan pada Tabel 6, dan Tabel 7.

Tabel 6. Data Nilai

\begin{tabular}{cccc}
\hline Nilai & Kondisi awal & Siklus I & Siklus II \\
\hline Terendah & 44 & 52 & 68 \\
Tertinggi & 92 & 94 & 100 \\
Jumlah & 2233 & 2333 & 2653 \\
Rata-rata & 69,8 & 72,9 & 82,9 \\
Persentase ketuntasan & $53,1 \%$ & $65,6 \%$ & $93,8 \%$ \\
\hline
\end{tabular}

Tabel 7. Profil Kelas Sebelum dan Sesudah Tindakan Penelitian

\begin{tabular}{cccc}
\hline Hasil Siswa & Kondisi Awal & Siklus I & Siklus II \\
\hline Nilai rata-rata & 69,8 & 72,9 & 82,9 \\
\hline Siswa yang tuntas KKM & 17 siswa & 21 siswa & 30 siswa \\
& $(53,1 \%)$ & $(65,6 \%)$ & $(93,8 \%)$ \\
\hline
\end{tabular}

Berdasarkan grafik di atas dapat ditunjukkan bahwa prestasi belajar siswa dengan menerapkan pembelajaran model aktif tipe CRH di setiap putaran mengalami peningkatan, yaitu: (1) Sebelum dilakukan tindakan penelitian kelas nilai rata-rata hasil belajar siswa adalah 69,8 dengan presentase prestasi belajar siswa hanya $53,1 \%$, (2) Setelah dilakukan tindakan pada siklus I nilai rata-rata prestasi belajar siswa mengalami peningkatan yaitu 72,9 dengan presentase ketuntasan 65,6\%, tetapi belum mencapai indikator yang diharapkan; (3) Pada siklus II nilai rata-rata prestasi belajar siswa meningkat yaitu menjadi 82,9 dengan presentase ketuntasan sebesar 93,8\% dan sudah mencapai indikator yang diharapkan maka penelitian tindakan kelas ini sudah berhasil.

Rata-rata prestasi belajar siswa pada kondisi awal 69,8 dengan persentase ketuntasan belajar siswa sebesar 53,1\%, pada siklus II naik menjadi 82,9 $\geq 80,0$ (indikator kinerja) dengan presentase ketuntasan belajar siswa sebesar 93,8 $\geq 85 \%$ (indikator kinerja). Jadi, indikator kinerja sudah tercapai sehingga tidak dilanjutkan ke siklus berikutnya.

Hasil penelitian ini sejalan dengan pendapat yang mengatakan bahwa model pembelajaran Course Review Horay terbukti berhasil meningkatkan hasil belajar pada mata pelajaran matematika, model ini dapat digunakan sebagai salah satu model untuk meningkatkan hasil belajar dalam pelaksanaan pembelajaran dikelas. Dalam rangka peningkatan kualitas pendidikan disekolah hendaknya salah satu model pembelajaran inovatif seperti model pembelajaran Course Review Horay dapat menjadi salah satu acuan dalam pengambilan kebijakan mengelola pendidikan di sekolah, karena model ini sudah terbukti dapat meningkatkan hasil belajar siswa. (Kasna, Sudhita, and Rati 2015).

Hasil penelitian menunjukkan bahwa model pembelajaran Course Review Horay mampu menigkatkan hasil belajar. Faktor yang menyebabkan hal tersebut, sejalan dengan pendapat berikut. Pada model pembelajaran Course Review Horay (CRH), siswa merasakan manfaat: 1) Pembelajaran lebih menarik dan lebih bersemangat dalam menerima materi yang disampaikan guru karena dalam prosesnya banyak diselingi dengan permainan; 2) Siswa terdorong untuk dapat terjun kedalam situasi pembelajaran yang menarik. 3) Pembelajaran tidak monoton; 4) Siswa lebih semangat belajar karena suasana belajar lebih menyenangkan.; 5) Adanya komunikasi dua arah, siswa dengan guru akan mampu berkomunikasi dengan baik, dapat melatih siswa agar dapat berbicara secara kritis, kreatif dan inovatif (Halidin and Ansar 2021).

Pengaruh model pembelajaran kooperatif tipe Course Review Horay (CRH) terhadap keaktifan belajar siswa diperoleh bahwa dengan menggunakan model pembelajaran kooperatif tipe Course Review Horay $(\mathrm{CRH})$ aktivitas belajar siswa tergolong aktif. Siswa di kelas tidak hanya berperan sebagai penerima pelajaran melalui penjelasan guru secara verbal, tetapi siswa juga berperan aktif dengan berfikir, bekerjasama, berdiskusi untuk menyelesaikan masalah yang ada. Kegiatan ini juga memlatih sikap percaya diri siswa dalam proses pembelajaran. (Hasibuan 2019) 


\section{Simpulan}

Berdasarkan hasil penelitian dapat disimpulkan bahwa: "Model pembelajaran aktif CRH dapat meningkatkan prestasi belajar Matematika siswa kelas VII H semester I SMP Negeri 2 Weru tahun pelajaran 2019/2020. Hasil penelitian ini menunjukkan adanya peningkatan pada prestasi belajar Matematika siswa. Hal ini dapat dilihat dari nilai rata-rata prestasi belajar Matematika siswa juga mengalami peningkatan yaitu sebelum tindakan sebesar 69,8, pada siklus I sebesar 72,9 dan pada siklus II sebesar 82,9. Selain itu, persentase ketuntasan belajar siswa, yaitu sebelum tindakan sebesar $53,1 \%$, pada siklus I sebesar $65,6 \%$ dan pada siklus II sebesar $93,8 \%$.

\section{References}

Aprilianawati, Diah Mutiara, Nizaruddin Nizaruddin, and Muhammad Prayito. 2019. "Efektivitas Model Pembelajaran Kooperatif Tipe Course Review Horay Berbantuan Lectora Ditinjau Dari Gaya Belajar Terhadap Prestasi Belajar Matematika Siswa." Imajiner: Jurnal Matematika Dan Pendidikan Matematika 1 (6): 357-63. https://doi.org/10.26877/imajiner.v1i6.4865.

Ayuwanti, Irma. 2017. "Meningkatkan Aktivitas Dan Hasil Belajar Matematika Menggunakan Model Pembelajaran Kooperatif Tipe Group Investigation Di SMK Tuma'ninah Yasin Metro." SAP (Susunan Artikel Pendidikan) 1 (2): 105-14. https://doi.org/10.30998/sap.v1i2.1017.

Hadi, Sutarto, and Maidatina Umi Kasum. 2015. "Pemahaman Konsep Matematika Siswa SMP Melalui Penerapan Model Pembelajaran Kooperatif Tipe Memeriksa Berpasangan (Pair Checks)." EDU-MAT: Jurnal Pendidikan Matematika 3 (1): 59-66. https://doi.org/10.20527/edumat.v3i1.630.

Halidin, and Ansar. 2021. "EFEKTIVITAS MODEL PEMBELAJARAN COURSE REVIEW HORAY ( CRH ) TERHADAP HASIL BELAJAR MATEMATIKA SISWA Pendidikan Matematika , Universitas Sembilanbelas November Kolaka, Indonesia E-Mail : Abstrak PENDAHULUAN Dalam Pembelajaran Dibutuhkan Suatu Model Pembela." AKSIOMA: Jurnal Program Studi Pendidikan Matematika 9 (4): 1067-75.

Hasibuan, Lili Rohanita. 2019. "Pengaruh Model Pembelajaran Kooperatif Tipe Course Review Horay (CRH) Terhadap Hasil Belajar Matematika Siswa Pada Materi Persamaan Linear Satu Variabel Di Kelas VII SMP Negeri Rantau Selatan.” Jurnal Pembelajaran Dan Matematika Sigma (Jpms) 5 (1): 11-15. https://doi.org/10.36987/jpms.v5i1.1238.

Kasna, I Fandy Prasastha, I Wyn Romi Sudhita, and Ni Wyn Rati. 2015. "PENERAPAN MODEL PEMBELAJARAN CRH ( COURSE REVIEW HORAY ) DENGAN BANTUAN PERMAINAN ULAR TANGGA UNTUK MENINGKATKAN HASIL BELAJAR SISWA KELAS II SD Universitas Pendidikan Ganesha." E-Journal PGSD Universitas Pendidikan Ganesha 3 (1): 1.

Kusfabianto, Igantius Jodi, Firosalia Kristin, and Indri Anugraheni. 2019. "Penerapan Model Pembelajaran Course Review Horay Untuk Meningkatkan Keaktifan Dan Hasil Belajar Matematika Kelas IV SD.” Jurnal Teori Dan Aplikasi Matematika 3 (2): 87-92.

Maryam, Siti, Muh. Hasbi, and ABD. Hamid. 2016. "Penerapan Model Pembelajaran Kooperatif Tipe Course Review Horay Untuk Meningkatkan Hasil Persegi Panjang Di Kelas Vii Smp Negeri 2 Marawola." Jurnal Elektronik Pendidikan Matematika Tadulako 04 (01): 116-30.

Muhandaz, Ramon, Ovi Trisnawita, and R. Risnawati. 2018. "Pengaruh Model Pembelajaran Course Review Horay Terhadap Kemampuan Pemahaman Konsep Matematis Berdasarkan Kemandirian Belajar Siswa SMK Pekanbaru." JURING (Journal for Research in Mathematics Learning) 1 (2): 137. https://doi.org/10.24014/juring.v1i2.6552.

Ningrum, Windi Kristanti, Luh Putu Putrini Mahadewi, and I Gusti Ngurah Japa. 2019. "Pengaruh Model Pembelajaran Course Review Horay Terhadap Hasil Belajar Pada Materi Menganalisis Bearing." STEAM Engineering 1 (1): 22-25. https://doi.org/10.37304/jptm.v1i1.112. 
Nurhayati, and Novi Marliani. 2019. "Implementasi Model Pembelajaran Kooperatif Tipe Course Review Horay ( CRH ) Terhadap Kemampuan Pemecahan Masalah Matematika.” JKPM (Jurnal Kajian Pendidikan Matematika) 5 (1): 29-36.

Pratama, Diyan, Herry Agus Susanto, and Annisa Prima Exacta. 2020. "Model Pembelajaran Kooperatif Think Pair Share Berbasis Lesson Study Terhadap Minat Dan Prestasi Belajar." ABSIS: Mathematics Education Journal 1 (2). https://doi.org/10.32585/absis.v1i2.571.

Romadhoni, Mesti Fajar, and Stefanus C. Relmasira. 2018. "Perbedaan Pengaruh Penerapan Model Pembelajaran Course Review Horay Dan Quantum Teaching Dilihat Dari Hasil Belajar Matematika Siswa Kelas 3 SD.” Scholaria: Jurnal Pendidikan Dan Kebudayaan 8 (1): 93104. https://doi.org/10.24246/j.js.2018.v8.i1.p93-104.

Suprihartini. 2019. "Peningkatan Aktivitas Dan Hasil Belajar Matematika Tema Pengalamanku Dengan Model Pembelajaran Course Review Horay." ANARGYA: Jurnal Ilmiah Pendidikan Matematika 2 (2): 116-23.

Suryani, Asih, Maulana, and Julia. 2016. "Pengaruh Pendekatan Course Review Horay (Crh) Terhadap Pemahaman Matematis Dan Motivasi Belajar Matematika Siswa Sekolah Dasar Pada Materi Penjumlahan Dan Pengurangan Bilangan Bulat.” Jurnal Pena Ilmiah 1 (1): 8190. https://doi.org/10.23819/pi.v1i1.2934.

Zakiah, Ifa Roselina, Krisdianto Hadi Prasetyo, and Erika Laras Astutiningtyas. 2019. "Meningkatkan Aktivitas Dan Hasil Belajar Melalui Pembelajaran Kooperatif Tipe Make a Match." ABSIS: Mathematics Education Journal 1 (2). https://doi.org/10.32585/absis.v1i2.362. 